\title{
Characterization of gluten processing streams
}

\author{
K.D. Rausch ${ }^{\text {a }}$, C.I. Thompson ${ }^{\text {a }}$, R.L. Belyea ${ }^{\text {b,* }}$, T.E. Clevenger ${ }^{c}$, M.E. Tumbleson ${ }^{\mathrm{d}}$ \\ a Department of Agricultural Engineering, University of Illinois at Urbana-Champaign, Urbana 61801, USA \\ ${ }^{\mathrm{b}}$ Department of Animal Science, University of Missouri, 115 ASRC, Columbia, MO 65211, USA \\ ${ }^{\mathrm{c}}$ Department of Civil Engineering, University of Missouri, Engineering Building East, Columbia, MO 65211, USA \\ ${ }^{\mathrm{d}}$ College of Veterinary Medicine, University of Illinois at Urbana-Champaign, Urbana 61801, USA
}

Received 1 November 2001; received in revised form 17 December 2002; accepted 21 January 2003

\begin{abstract}
Corn gluten meal (CGM) is a major coproduct of corn wet milling; it has value because of high protein. However, variation in composition and high $\mathrm{P}$ content reduce market value. Data that characterize gluten streams would be helpful in identifying key processing steps that could be modified to improve the quality of CGM and increase processing efficiency. Few data are published in the literature on the detailed composition of gluten processing streams. The objective was to characterize the gluten process streams in a corn wet milling plant.

Samples were obtained from one plant over a six month period and analyzed for dry matter (DM), total N (protein), ash and elements. DM and macroelement content of the streams were increased significantly during processing. Ash, priority pollutant elements and microelement concentrations were low and of little concern. About $38 \%$ of the $\mathrm{N}$ (protein) in light gluten was not recovered in the CGM; most of this was lost at the gluten thickener step into the gluten thickener overflow. Much of the P also was removed at this step. Modification of the gluten thickener overflow to increase $\mathrm{N}$ and reduce $\mathrm{P}$ could make CGM a more valuable coproduct and improve processing efficiency.
\end{abstract}

(C) 2003 Elsevier Science Ltd. All rights reserved.

Keywords: Coproducts; Gluten processing; Corn wet milling; Corn gluten meal; Chemical composition

\section{Introduction}

The primary commodity from corn wet milling is starch, which is used in the manufacture of high fructose corn syrup, lactic acid derivatives, ethanol and other products. Increase in demand for starch and starch products has increased the amount of corn processed by the US wet milling industry from 628 million bu in 1982 to 1449 million bu in 2000 (ERS, 2000). Corn gluten meal (CGM) is a major coproduct of wet milling. CGM is produced after germ, fiber and starch have been removed from processed corn; this results in light gluten (LG). LG is concentrated first with a centrifuge called the gluten thickener to produce heavy gluten (HG). HG is dewatered further using a vacuum belt filter to form gluten cake (GC). Finally, GC is dried using rotary drum dryers to form CGM (Fig. 1). The overflow stream

\footnotetext{
${ }^{*}$ Corresponding author. Tel.: +1-573-882-6354; fax: +1-573-8826827.

E-mail address: belyear@missouri.edu (R.L. Belyea).
}

from the gluten thickener (GTOF) and filtrate passing through the vacuum belt filter (VBFF) is recycled in the wet milling process, and eventually become part of other coproducts. CGM has high protein content and is fed mainly to non ruminants (poultry, swine, companion animals). Composition of CGM, like many corn processing coproducts, can vary significantly from batch to batch, which affects market value (Belyea et al., 1998). In addition, CGM contains high $\mathrm{P}$ content. High $\mathrm{P}$ content raises environmental concerns, because animal food ingredients with high $\mathrm{P}$ content can contribute to excessive $\mathrm{P}$ in animal wastes and create waste disposal difficulties.

There are few detailed data published in the literature on the composition of the processing streams from which CGM is produced; such data could provide insight on the causes of variation in composition. In addition, characterization data along with flow data could be used to identify critical control points for modifying streams. For example, in the centrifugation of LG, there are no published data to show how much $\mathrm{P}$ remains in 


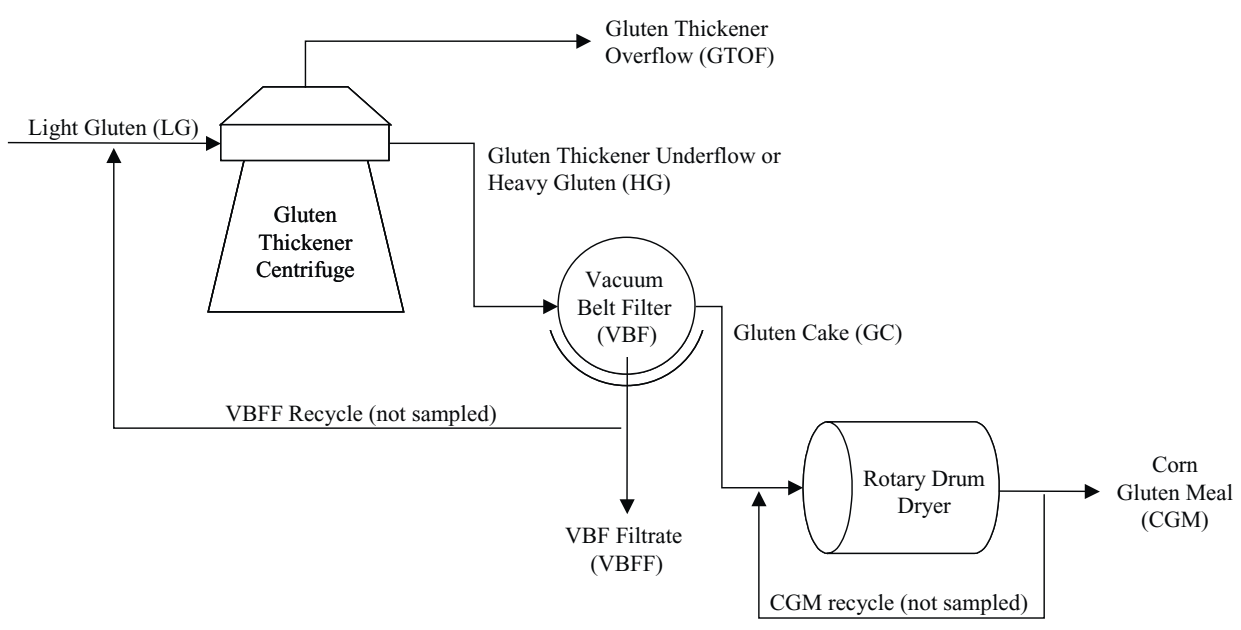

Fig. 1. Schematic of the gluten process and sampling locations.

the HG and how much travels in the overflow (Fig. 1). This has a significant impact on potential strategies to alter the composition of CGM; if most of the $\mathrm{P}$ were carried in the overflow, it might be possible to process (filter) the overflow to remove at least some of the P. The objective was to measure the composition of gluten process streams and determine flow of specific nutrients.

\section{Methods}

Samples were obtained from six gluten processing streams in a commercial corn wet milling facility. These were: LG stream just prior to entering the gluten thickener centrifuge, GTOF, gluten thickener underflow (or HG), VBFF, GC after the vacuum belt filter, and CGM following the rotary drum dryer. The gluten process and the stream sampling points are illustrated in Fig. 1.

Six samples were taken from each stream over a six month period; each represented one day of processing. On each sample day, aliquots $\left(\begin{array}{lll}\sim & 1\end{array}\right)$ were obtained, cooled and shipped overnight (under ice) to the University of Missouri for analyses. Analyses were completed within five days of receipt (seven days after procurement); previous work (Rausch et al., in press) showed that these materials did not have detectable changes in composition if analyzed within seven days. Samples were kept refrigerated during the analysis period.

Dry matter (DM) content of each sample was determined as weight loss when subsamples were dried overnight in a drying oven $\left(105^{\circ} \mathrm{C}\right)$. Total nitrogen ( $\mathrm{TNw}$ ) on wet (as is) samples was measured by thermal conductivity (Leco, 1994); total nitrogen dry basis (TNd) was calculated as $\mathrm{TNw}$ corrected for DM content $(\mathrm{TNd}=\mathrm{TNw} / \mathrm{DM}$ content $)$. Ash content on an as basis (Ashw) was determined as weight loss when sam- ples (as is) were heated in a muffle furnace overnight at $550{ }^{\circ} \mathrm{C}$ (AOAC, 1984). Ashd was calculated as Ashw corrected for DM content. Organic matter was estimated as $100 \%-A s h d \%$. Element concentrations were determined by inductive coupled plasma (Clevenger, 1990). Data were analyzed as a one way analysis of variance for effect of stream using the general linear model procedure of SAS (1989); means (as least squares means) were compared by least significant difference, when main effects were significant $(P<0.05)$.

\section{Results and discussion}

Mean concentrations of nutrients in the stream samples are presented in Table 1. DM concentrations of the streams varied considerably but generally increased at each processing step. Mean DM of LG (the original feed stream) was $4.93 \mathrm{~g} / 100 \mathrm{~g}$, which was similar to values in other studies (Rausch et al., in press; Thompson, 2001). At the gluten thickener step, DM was increased significantly to $15.43 \mathrm{~g} / \mathrm{kg}$ in $\mathrm{HG}$, and at the vacuum belt filter press step, it was significantly increased again to $40.79 \mathrm{~g} / \mathrm{kg}$ in GC. Finally, DM was increased $(P<0.05)$ to $87.52 \mathrm{~g} / \mathrm{kg}$ in CGM following drying. DM concentrations of GTOF and VBFF (2.49 and $3.61 \mathrm{~g} / \mathrm{kg}$, respectively) were not significantly different from each other or from that of LG. TNw concentrations increased at each processing step, similar to increases noted for DM. TNw concentrations of $\mathrm{HG}$, GC and CGM (1.22, 4.71 and $10.12 \mathrm{~g} / \mathrm{kg}$ ) were significantly different from each other and from LG (Table 1). TNw concentrations of GTOF $(0.22 \mathrm{~g} / \mathrm{kg})$ and VBFF $(0.34 \mathrm{~g} / \mathrm{kg})$ were not different from LG $(0.39 \mathrm{~g} / \mathrm{kg})$. When samples were corrected for DM content, $\mathrm{TNd}$ concentrations were not significantly different among streams. Ashw concentrations were very low, due to the dilute concentrations of most of the streams, and they 
Table 1

Nutrient content $(\mathrm{g} / 100 \mathrm{~g})$ of gluten process streams

\begin{tabular}{|c|c|c|c|c|c|c|}
\hline Stream & $\mathrm{DM}$ & $\mathrm{TNw}$ & $\mathrm{TNd}$ & Ashw & Ashd & Organic matter \\
\hline Light gluten & $4.93^{\mathrm{a}}$ & $0.39^{\mathrm{a}}$ & 9.06 & $0.01^{\mathrm{a}}$ & $3.83^{\mathrm{a}}$ & $96.17^{\mathrm{a}}$ \\
\hline Gluten thickener overflow & $2.49^{\mathrm{a}}$ & $0.22^{\mathrm{a}}$ & 8.98 & $0.03^{\mathrm{a}}$ & $7.63^{\mathrm{b}}$ & $92.37^{\mathrm{b}}$ \\
\hline Heavy gluten & $15.43^{\mathrm{b}}$ & $1.22^{\mathrm{b}}$ & 9.73 & $0.11^{\mathrm{b}}$ & $2.54^{\mathrm{a}}$ & $97.46^{\mathrm{a}}$ \\
\hline Filtrate from vacuum belt filter & $3.61^{\mathrm{a}}$ & $0.34^{\mathrm{a}}$ & 9.74 & $0.09^{\mathrm{b}}$ & $6.97^{\mathrm{b}}$ & $93.03^{\mathrm{b}}$ \\
\hline Gluten cake & $40.79^{c}$ & $4.71^{\mathrm{c}}$ & 11.53 & $0.93^{\mathrm{c}}$ & $3.45^{\mathrm{a}}$ & $96.55^{\mathrm{a}}$ \\
\hline Corn gluten meal & $87.52^{\mathrm{d}}$ & $10.12^{\mathrm{d}}$ & 11.56 & $0.66^{\mathrm{d}}$ & $1.55^{\mathrm{a}}$ & $98.45^{\mathrm{a}}$ \\
\hline Standard error & 1.78 & 0.16 & 0.92 & 0.16 & 0.16 & 0.16 \\
\hline
\end{tabular}

$\mathrm{DM}=$ dry matter; $\mathrm{TNw}$ and $\mathrm{TNd}=$ total nitrogen on wet and on dry basis, respectively; Ashw and Ashd=ash content on wet and dry basis, respectively.

${ }^{a-d}$ Means with unlike letters and in the same column differ $(P<0.05)$.

increased significantly at the gluten thickener and vacuum belt filter processing steps. Ashd was partitioned differently from DM and TN. Significantly more Ashd was recovered in GTOF $(7.63 \mathrm{~g} / \mathrm{kg})$ and VBFF $(6.97 \mathrm{~g} /$ $\mathrm{kg})$ than in $\mathrm{HG}, \mathrm{GC}$ and CGM $(2.54,3.45$ and $1.55 \mathrm{~g} / \mathrm{kg}$, respectively, Table 1).

Priority pollutant concentrations (Table 2) were similar among the streams; most were in very low concentrations and of little concern (Clevenger, 1990).

Concentrations of $\mathrm{Cu}$ and $\mathrm{Zn}$ were higher than the others but also were not a concern; both are essential nutrients and concentrations in CGM were similar to those found in other animal foodstuffs (NRC, 1982). Concentrations of microelements (Table 2) varied with the stream. Some, such as Co, Mo and V were in low concentrations and were relatively uniform across streams. Others, such as Al, Ba, B, Fe, Mn and Si de- creased from the LG samples to the VBFF samples and then increased in GC and CGM. Zinc generally decreased from LG to CGM. These changes appear to reflect the recycling of process water (and compounds contained therein) back into processing streams.

Processing progressively reduced macroelement concentrations of the streams (Table 3). Decreases were sizeable for some elements. Concentration of $\mathrm{K}$ in CGM $(2127 \mathrm{mg} / \mathrm{kg})$ was significantly lower than in LG $(20775$ $\mathrm{mg} / \mathrm{kg}$ ), nearly a $10 \mathrm{X}$ decrease. Phosphorus concentration of CGM was $6077 \mathrm{~g} / \mathrm{kg}$, compared to $10915 \mathrm{~g} / \mathrm{kg}$ in LG. Concentrations of the other macroelements decreased similarly from LG to CGM (Table 3). We presume that differences in concentrations among streams reflect movement of elements soluble in process water removed at the gluten thickening step (into the GTOF) and at the vacuum belt filtration step (into the VBFF).

Table 2

Priority pollutant and element concentrations $(\mathrm{mg} / \mathrm{kg}$ dry basis) of gluten process streams

\begin{tabular}{|c|c|c|c|c|c|c|}
\hline Element & Light Gluten & $\begin{array}{l}\text { Gluten thickener } \\
\text { overflow }\end{array}$ & Heavy gluten & $\begin{array}{l}\text { Filtrate from } \\
\text { vacuum belt filter }\end{array}$ & Gluten cake & Corn gluten meal \\
\hline \multicolumn{7}{|c|}{ Priority pollutants } \\
\hline $\mathrm{Ag}$ & 2.0 & $<2$ & $<2$ & $<2$ & $<2$ & $<2$ \\
\hline As & $<20$ & $<20$ & $<20$ & $<20$ & $<20$ & $<20$ \\
\hline $\mathrm{Cd}$ & $<0.6$ & $<0.6$ & $<0.6$ & $<0.6$ & $<0.5$ & $<0.6$ \\
\hline $\mathrm{Cr}$ & $<2.0$ & $<2$ & $<2$ & $<2$ & $<2$ & $<2$ \\
\hline $\mathrm{Cu}$ & 10 & 3 & 10 & 15 & 13 & 12 \\
\hline $\mathrm{Ni}$ & 3.7 & 2.5 & $<3$ & 3 & $<3$ & $<3$ \\
\hline $\mathrm{Pb}$ & $<10$ & $<10$ & $<10$ & $<10$ & $<10$ & $<10$ \\
\hline $\mathrm{Sb}$ & $<3$ & - & $<20$ & $<20$ & $<20$ & $<20$ \\
\hline $\mathrm{Se}$ & $<7$ & $<7$ & $<7$ & $<7$ & $<7$ & $<7$ \\
\hline $\mathrm{Zn}$ & 90 & 120 & 27 & 106 & 27 & 31 \\
\hline \multicolumn{7}{|c|}{ Microelements } \\
\hline $\mathrm{Al}$ & 66 & 22 & 59 & 45 & 103 & 107 \\
\hline $\mathrm{Ba}$ & 0.57 & 0.29 & 0.39 & 0.42 & 0.96 & 0.59 \\
\hline B & 11 & 15 & 4.0 & 13 & 3.0 & 2.8 \\
\hline $\mathrm{Co}$ & 2 & $<3$ & $<2$ & 3 & 3 & 3 \\
\hline $\mathrm{Fe}$ & 123 & 73 & 82 & 94 & 174 & 183 \\
\hline $\mathrm{Mn}$ & 20 & 28 & 6 & 24 & $<6$ & 6 \\
\hline Mo & $<2$ & 2 & $<2$ & $<2$ & $<2$ & 38 \\
\hline $\mathrm{Si}$ & 200 & 173 & 105 & 174 & 186 & 187 \\
\hline $\mathrm{Sr}$ & $<4.0$ & 0.3 & $<0.3$ & 0.34 & $<0.3$ & $<0.3$ \\
\hline $\mathrm{Zn}$ & 90 & 120 & 27 & 106 & 27 & 31 \\
\hline V & $<4.0$ & $<4$ & $<4$ & $<4$ & $<4$ & $<4$ \\
\hline
\end{tabular}


Table 3

Concentrations ( $\mathrm{mg} / \mathrm{kg}$ dry basis) of macroelements in the gluten process streams

\begin{tabular}{|c|c|c|c|c|c|c|c|}
\hline Element & Light gluten & $\begin{array}{l}\text { Gluten thickener } \\
\text { overflow }\end{array}$ & Heavy gluten & $\begin{array}{l}\text { Filtrate from } \\
\text { vacuum belt } \\
\text { filter }\end{array}$ & Gluten cake & $\begin{array}{l}\text { Corn gluten } \\
\text { meal }\end{array}$ & Standard error \\
\hline $\mathrm{Ca}$ & $301^{\mathrm{a}}$ & $420^{\mathrm{a}}$ & $67^{\mathrm{b}}$ & $352^{\mathrm{a}}$ & $51^{\mathrm{b}}$ & $69^{b}$ & 29.5 \\
\hline K & $20,775^{a}$ & $32,450^{\mathrm{b}}$ & $4787^{a}$ & $24,875^{\mathrm{b}}$ & $1290^{\mathrm{a}}$ & $2127^{a}$ & 247 \\
\hline $\mathrm{Mg}$ & $3855^{\mathrm{a}}$ & $5407^{b}$ & $940^{\mathrm{a}}$ & $4570^{\mathrm{b}}$ & $473^{\mathrm{b}}$ & $587^{\mathrm{b}}$ & 369 \\
\hline $\mathrm{Na}$ & $254^{\mathrm{ab}}$ & $454^{\mathrm{b}}$ & $52^{\mathrm{c}}$ & $340^{\mathrm{a}}$ & $33^{\mathrm{c}}$ & $221^{\mathrm{a}}$ & 77 \\
\hline $\mathrm{P}$ & $10,915^{\mathrm{a}}$ & $13,162^{\mathrm{a}}$ & $4300^{\mathrm{b}}$ & $12,300^{\mathrm{a}}$ & $5715^{\mathrm{b}}$ & $6077^{b}$ & 911 \\
\hline $\mathrm{Zn}$ & $90^{\mathrm{a}}$ & $120^{\mathrm{b}}$ & $27^{\mathrm{c}}$ & $106^{\mathrm{ab}}$ & $27^{\mathrm{c}}$ & $31^{\mathrm{c}}$ & 7.1 \\
\hline
\end{tabular}

${ }^{\mathrm{a}-\mathrm{c}}$ Means with unlike letters in the same row differ $(P<0.05)$.

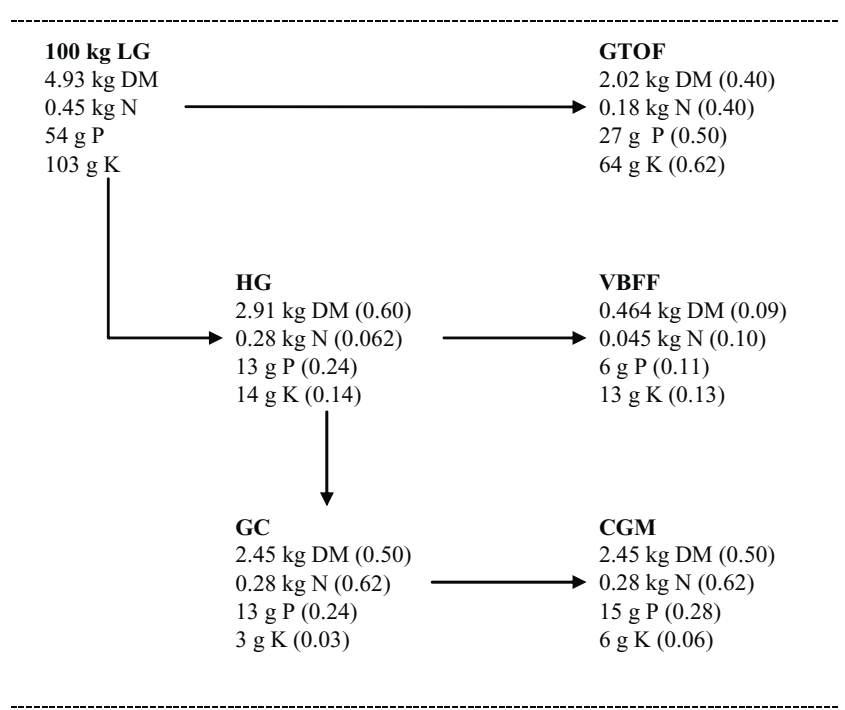

Fig. 2. Partition of DM, nitrogen (N), phosphorus $(\mathrm{P})$ and potassium $(\mathrm{K})$ in the gluten process stream. (See Fig. 1 and Table 1 for explanation of terms. Values in parentheses are proportion of original (LG) $\mathrm{DM}, \mathrm{N}, \mathrm{P}$ or $\mathrm{K}$ observed in each respective stream.)

The observed partition of absolute quantities of components in $100 \mathrm{~kg}$ of LG is presented in Fig. 2. A $100 \mathrm{~kg}$ sample of $\mathrm{LG}$ would be expected to contain 4.93 $\mathrm{kg} \mathrm{DM}, 0.45 \mathrm{~kg} \mathrm{~N}, 54 \mathrm{~g} \mathrm{P}$ and $103 \mathrm{~g} \mathrm{~K}$, based on analytical data from Tables 1 and 3. At the gluten thickener step, $2.91 \mathrm{~kg}$ of the $4.96 \mathrm{~kg}$ of the DM in LG were partitioned into the $\mathrm{HG}$, while $2.02 \mathrm{~kg}$ went into the GTOF. At the filter press stage, $2.45 \mathrm{~kg}$ of DM in $\mathrm{HG}$ was partitioned into $\mathrm{CG}$, while $0.46 \mathrm{~kg}$ of DM went into the VBFF. All of the DM in GC was recovered in CGM. Overall, 0.50 of the DM in LG was recovered in the CGM. The partitioning of $\mathrm{N}$ was similar to that of DM; of the $0.45 \mathrm{~kg} \mathrm{~N}$ in LG, $0.28 \mathrm{~kg}$ ended up in the CGM, and, overall, 0.62 of the $\mathrm{N}$ in LG was recovered in the CGM. The LG contained $54 \mathrm{~g} \mathrm{P}$ and $103 \mathrm{~g} \mathrm{~K} ; 15 \mathrm{~g}$ of $\mathrm{P}$ and $6 \mathrm{~g}$ of $\mathrm{K}$ were recovered in the CGM. Much of the $\mathrm{P}$ $(27 \mathrm{~g})$ and $\mathrm{K}(64 \mathrm{~g})$ were in the GTOF, but $14 \mathrm{~g} \mathrm{P}$ and 25 $\mathrm{g} \mathrm{K}$ were unaccounted for. The reason is not apparent.

Incomplete recovery of $\mathrm{N}$ (which we presume is protein) during processing of LG provides potential for increasing processing efficiency and improving the quality of CGM. About $38 \%$ of the $\mathrm{N}$ in LG was not recovered in CCM; if much of this $\mathrm{N}$ could be recovered, the protein content of CGM could be increased several $\%$ units, which would increase market value. Most of the $\mathrm{N}$ loss occurred at the gluten thickener stage, and presumably was carried in the GTOF. GTOF, like other processing water streams, eventually is returned to the initial corn processing steps, such as steeping. GTOF could be subjected to additional processing (i.e., filtration) to remove additional $\mathrm{N}$, prior to reuse. The removed $\mathrm{N}$ could be added back to the $\mathrm{CG}$ to increase the protein content of CGM, and the resulting process water would be considerably cleaner.

More nutrients were removed at the gluten thickener step as overflow (2.02 kg DM and $0.18 \mathrm{~kg} \mathrm{~N}$ per $100 \mathrm{~kg}$ ) than at the vacuum filter step as filtrate $(0.464 \mathrm{~kg} \mathrm{DM}$ and $0.045 \mathrm{~kg} \mathrm{~N}$ per 100). However, the ratio of $\mathrm{N}: \mathrm{DM}$ was about 1:10 in these two streams as well as GC and CGM. Thus, there did not appear to be any significant separation of $\mathrm{N}$ from other compounds (i.e., carbohydrate) during any of the processing steps. Much of the $\mathrm{P}$ in LG was removed during processing, but CGM still contained about $5.6 \mathrm{~g} / \mathrm{kg}$ DM (15 g P/2.67 kg DM), a typical concentration of $\mathrm{P}$ for CGM. If an additional $8 \mathrm{~g}$ of $P$ per $100 \mathrm{~kg} \mathrm{LG}$ could be removed during processing, $P$ content of CGM could be reduced to about $3 \mathrm{~g} / \mathrm{kg}$ DM. Low P content would allow producers to include larger amounts of CGM in diets to meet protein needs without greatly increasing $\mathrm{P}$ in animal wastes. Most of the $\mathrm{P}$ in LG was removed at the gluten thickener step, and, presumably, was carried in the GTOF. Therefore, additional processing to remove $\mathrm{P}$ should focus on the GTOF stream, prior to its reuse upstream.

\section{Conclusions}

The data in this paper were obtained from samples taken from one corn wet milling plant; obviously, inferences are specific for that particular processing plant. Wet mills contain equipment and processing methods that generally are similar to those described in this study, but some differences in processing technology 
could exist. Therefore, some characterization data for processing streams in other plants could differ from those in the present study. However, all wet mill plants use separation technologies to partition solids from water. Potential exists for improving recovery of $\mathrm{N}$ (protein) in certain streams and improving processing efficiency.

Priority pollutants were in very low concentrations and not a concern. This is not a surprising finding for a food processing plant; we previously showed that milk processing plants had very low priority pollutant concentrations in their processing streams (Clevenger, 1990). However, there are few published data to document priority pollutant concentrations for the processing streams in corn processing plants. Processing had little effect on either priority pollutants or microelements.

A considerable portion (38\%) of the $\mathrm{N}$ in LG was not recovered in the CGM but was carried in the GTOF. Loss of $\mathrm{N}$ (which we presume to be protein) has economic impact; if much of this protein could be retained, the protein content of CGM might be increased several $\%$ units, which would increase its market value. Improvements in membrane technology may provide an opportunity to process recycle streams such that more protein and less $\mathrm{P}$ are recovered in CGM.

\section{Acknowledgements}

The authors thank Angie Slottach and Loretta Lake (MU) for technical assistance.

\section{References}

AOAC, 1984. Official Methods of Analysis, 14th ed. Assoc. Offic. Analyt. Chem., Arlington, VA.

Belyea, R., Eckhoff, S., Wallig, M., Tumbleson, M., 1998. Variability in the nutritional quality of distillers solubles. Bioresour. Technol. 66, 207-212.

Clevenger, T.E., 1990. Safety and efficacy of food processing sludges as animal feed: chemical characterization. Res. J. Water Pollut. Control Fed. 62, 820-827.

ERS, 2000. Feed situation and outlook yearbook. FDS-2000, April. Market and Trade Economics Division, Economic Research Service, USDA.

Leco, 1994. FP-428 N Determinator. Leco Corp., St. Joseph, MI.

NRC, 1982. United States-Canadian Tables of Feed Composition, third ed. NAS-NRC. Nat. Acad. Press, Washington, DC.

Rausch, K., Thompson, C., Belyea, R., Tumbleson, M. Characterization of light gluten and light steepwater from a corn wet milling plant. Biores. Tech., in press.

SAS, 1989. SAS Guides: Statistics. Ver. 5. SAS Institute, Cary, NC.

Thompson, C.I., 2001. Evaluation of stainless steel microfiltration membranes for recovery of nutrients in corn wet milling coproduct streams. M.S. Thesis, Dept. Agric. Eng., University of Illinois at Urbana-Champaign, Urbana, IL. 